\title{
Forage yield and quality of Leucaena leucocephala and Guazuma ulmifolia in tropical silvopastoral systems
}

\author{
FERNANDO CASANOVA-LUGO, FRANCISCO J. SOLORIO-SÁNCHEZ, LUIS RAMÍREZ-AVILÉS, \\ JOSÉ A. CAAMAL-MALDONADO AND JUAN C. KU-VERA
}

Universidad Autónoma de Yucatán, Mérida, Yucatán, Mexico. www.uady.mx

Keywords: Forage trees, legumes, nutritive value, NDF, ADF.

\section{Introduction}

Low availability and quality of pastures during the dry season are common problems in tropical livestock production systems. However, several studies indicate that the use of trees and shrubs is a good alternative to overcome those problems (Ku-Vera et al. 1999), by producing foliage of higher nutritional value than that of forage grasses. In addition, their use could contribute to reforestation and restoration of degraded land (CasanovaLugo et al. 2010).

While several recent reports have focused on the incorporation of Leucaena leucocephala in silvopastoral systems (Murgueitio et al. 2011), there is little information about other tropical tree species with high forage production potential, such as Guazuma ulmifolia, which is broadly used in Southeast Mexico. In addition, little is known about the effect of season on forage quality of these species under a particular management regime.

Therefore, the aim of this study was to evaluate the yield and forage quality of $L$. leucocephala and $G$. ulmifolia in the subhumid tropics during the dry and rainy seasons.

\section{Methods}

The experiment was undertaken at the Campus of Biological and Agricultural Sciences, University of Yucatán (UADY), in the Yucatán Peninsula, Mexico, from January to December 2009. Average annual rainfall is 953 $\mathrm{mm}$ and average annual temperature $26^{\circ} \mathrm{C}$. The area is located within a karst plateau characterized by a flat or gently rolling relief. Soils are shallow, heterogeneous, rocky (limestone) and clay-loam, with a $\mathrm{pH}$ of 7.5 to 7.8 (Bautista et al. 2005).

Correspondence: Luis Ramírez-Avilés, Universidad Autónoma de Yucatán, Carretera Mérida-Xmatkuil km 15.5, Apdo. Postal 4-116 Itzimná, C.P. 97100, Mérida, Yucatán, Mexico.

Email: raviles@uady.mx
In 2004, seedlings of $L$. leucocephala and $G$. ulmifolia were planted within $5 \times 10 \mathrm{~m}$ plots (experimental unit), in rows $2.0 \mathrm{~m}$ apart and with $0.5 \mathrm{~m}$ between plants. A complete randomized block design with 3 replicates was used. Before starting the current experiment, a standardization pruning at $1 \mathrm{~m}$ height was performed. During the dry season, drip irrigation was applied for 3 hours in the mornings, twice per week. Ten plants of all species, within each experimental unit, were pruned to a height of $1.0 \mathrm{~m}$ at 3-month intervals (2 prunings per season). After each pruning, the biomass was collected and separated into edible and non-edible material. Three samples were taken from the edible portion (leaves and tender stems) of both species, approximately $1 \mathrm{~kg}$ each, and were dried at $60{ }^{\circ} \mathrm{C}$ in a forced-air oven until constant weight. Dry forage subsamples (leaves and tender stems) were ground and analyzed for neutral detergent fiber (NDF) and acid detergent fiber (ADF) using an ANKOM (Macedon, NY) A200 fiber analyzer. Crude protein (CP) was estimated using a Leco CN 2000 elemental analyzer $(\mathrm{N} \times$ 6.25). Dry matter digestibility (DMD) was estimated based on ADF concentration, according to Ayala-Burgos et al. (2006).

Forage yield data were analyzed with a one-way ANOVA to examine the effect of season. For chemical composition, a multivariate analysis of variance (MANOVA) was used, with a PROC GLM (SAS Institute). Where significant differences were found, means were compared using Tukey's statistic $(\mathrm{P} \leq 0.05)$.

\section{Results and Discussion}

Forage yield, CP concentration and DMD of $L$. leucocephala showed no significant changes over the 2 seasons, with average values of $3.45 \mathrm{t} \mathrm{DM} / \mathrm{ha}, 22.8 \%$ and $66.7 \%$, respectively. However, the concentrations of $\mathrm{NDF}$ and ADF were greater during the rainy season (Table 1). In contrast, forage yield and NDF of $G$. ulmifolia were higher in the rainy season than in the dry 
season, while the reverse occurred with ADF (Table 1). However, CP concentration of G. ulmifolia (14.5\% on average) and DMD (65.9\%) were not influenced by season.

Table 1. Edible forage yield and quality of L. leucocephala and G. ulmifolia during the dry and rainy seasons in Yucatan, Mexico.

\begin{tabular}{lccccc}
\hline Season & $\begin{array}{c}\text { Yield } \\
(\mathrm{t} \mathrm{DM} / \mathrm{ha})\end{array}$ & $\begin{array}{c}\text { CP } \\
(\%)\end{array}$ & $\begin{array}{c}\text { NDF } \\
(\%)\end{array}$ & $\begin{array}{c}\text { ADF } \\
(\%)\end{array}$ & $\begin{array}{c}\text { DMD } \\
(\%)\end{array}$ \\
\hline \multicolumn{5}{c}{ Leucaena leucocephala } \\
Dry & 3.5 & 22.2 & $41.3 \mathrm{~b}^{1}$ & $23.8 \mathrm{~b}$ & 70.2 \\
Rainy & 3.4 & 23.4 & $49.0 \mathrm{a}$ & $32.8 \mathrm{a}$ & 63.2 \\
s.e. & 0.55 & 5.65 & 3.75 & 8.50 & 7.23 \\
\multicolumn{5}{c}{ Guazuma ulmifolia } \\
Dry & $3.7 \mathrm{~b}$ & 15.0 & $44.0 \mathrm{~b}$ & $33.6 \mathrm{a}$ & 62.4 \\
Rainy & $5.3 \mathrm{a}$ & 14.0 & $47.2 \mathrm{a}$ & $24.8 \mathrm{~b}$ & 69.4 \\
s.e. & 0.65 & 3.2 & 3.23 & 5.42 & 4.30 \\
\hline
\end{tabular}

${ }^{1}$ Means within columns and species followed by different letters are significantly different (Tukey's statistic).

Woody species have different capability to take advantage of good conditions in the wet and to combat dry conditions; some show high biomass production in the dry in spite of the water limitations, as was the case for L. leucocephala, while others show a decline in production, as suggested by Tamayo-Chim et al. (2012). A reduction in photoperiod and air temperature coincides with the end of the rainy season, which reduces growth despite the availability of adequate soil moisture. G. ulmifolia seemed capable of utilizing the favorable conditions in the rainy season to produce high DM yields, but showed lower growth in the dry season, while L. leucocephala maintained a similar level of growth throughout. Some rain was recorded in the dry season, although erratic and of short duration; this was sufficient to promote plant growth as temperature and photoperiod were appropriate for a response to available soil moisture.

These two facts, the ability of L. leucocephala to search for limited soil-water and some rainfall events during the dry season, could explain the fact that this legume had similar behavior in both seasons. Moreover, important nutritional parameters, such as $\mathrm{CP}$ and DMD, were not affected by season, possibly due to the ability to maintain high reserves of $\mathrm{C}$ in the tissues (Lizárraga et al. 2001). However, L. leucocephala fiber (NDF and $\mathrm{ADF}$ ) concentrations during the rainy season (almost $19 \%$ higher than in the dry season) could be due to the high and rapid regrowth ability of this legume, and the long pruning interval ( 3 months) used in this study. In contrast, $G$. ulmifolia developed more slowly than $L$. leucocephala and, therefore, the pruning interval could have been more appropriate for this species than for $L$. leucocephala. As a consequence, fiber content was less affected by season than in the case of L. leucocephala.

\section{Conclusions}

Both L. leucocephala and G. ulmifolia showed potential for production of high quality forage in Mexico. While L. leucocephala can maintain good forage yield throughout the year, growth of G. ulmifolia declines during the dry season. However, total DM production favored G. ulmifolia, although the crude protein concentration of L. leucocephala forage was higher in both seasons. Further research is needed to determine the appropriate interval between prunings for the individual species.

\section{Acknowledgments}

The authors are grateful to Consejo Nacional de Ciencia y Tecnología (CONACYT) for the project FORDECyT, key 117072. We thank CONACYT also for the support granted to M.Sc. Fernando Casanova-Lugo to undertake his Ph.D. studies at the University of Yucatán, Mexico.

\section{References}

Ayala-Burgos A; Cetina-Góngora R; Captillo-Leal C; ZapataRamos C; Sandoval-Castro C. 2006. Composición química-nutricional de árboles forrajeros. Universidad Autónoma de Yucatán, Mérida, Yucatán, Mexico.

Bautista F; Palma-López D; Huchin-Malta W. 2005. Actualización de la clasificación de los suelos del estado de Yucatán. In: Bautista F; Palacio G, eds. Caracterización y manejo de los suelos de la península de Yucatán: Implicaciones agropecuarias, forestales y ambientales. UACAM (Universidad Autónoma de Campeche)-UADY (Universidad Autónoma de Yucatán), Campeche, México. p. $105-122$.

Casanova-Lugo F; Ramírez-Avilés L; Solorio-Sánchez FJ. 2010. Effect of pruning interval on foliage and root biomass in forage tree species in monoculture and in association. Tropical and Subtropical Agroecosystems $12: 33-41$.

Ku-Vera JC; Ramírez-Avilés L; Jiménez-Ferrer G; AlayónGamboa JA; Ramírez-Cancino L. 1999. Árboles y arbustos para la producción animal en el trópico. In: Sánchez MD; Rosales MM, eds. Agroforestería para la producción animal en América Latina. FAO (Food and Agriculture Organization of the United Nations), Rome, Italy. p. 231-258. 
Lizárraga SH; Solorio SFJ; Sandoval CCA. 2001. Evaluación agronómica de especies arbóreas para la producción de forraje en la Península de Yucatán. Livestock Research for Rural Development 13(6).

www.lrrd.org/lrrd13/6/liza136.htm (18 March 2014).

Murgueitio E; Calle Z; Uribe F; Calle A; Solorio B. 2011. Native trees and shrubs for the productive rehabilitation of tropical cattle ranching lands. Forest Ecology and Management 261:1654-1663.

Tamayo-Chim M; Reyes-García C; Orellana R. 2012. A combination of forage species with different responses to drought can increase year-round productivity in seasonally dry silvopastoral systems. Agroforestry Systems 84: 287-297.

(C) 2014

\section{(c) (i) (2) (2)}

Tropical Grasslands-Forrajes Tropicales is an open-access journal published by Centro Internacional de Agricultura Tropical (CIAT). This work is licensed under a Creative Commons Attribution-NonCommercial-ShareAlike 3.0 Unported License. To view a copy of this license, visit http://creativecommons.org/licenses/by-nc-sa/3.0/ 
Casanova-Lugo F; Solorio-Sánchez FJ; Ramírez-Avilés L. 2014. Forage yield and quality of Leucaena leucocephala and Guazuma ulmifolia in tropical silvopastoral systems. Tropical Grasslands - Forrajes Tropicales 2:24-26.

DOI: $10.17138 / \mathrm{TGFT}(2) 24-26$

This paper was presented at the $22^{\text {nd }}$ International Grassland Congress, Sydney, Australia, 15-19 September 2013. Its publication in Tropical Grasslands - Forrajes Tropicales is the result of a co-publication agreement with the IGC Continuing Committee. Except for adjustments to the journal's style and format, the text is essentially the same as that published in: Michalk LD; Millar GD; Badgery WB; Broadfoot KM, eds. 2013. Revitalising Grasslands to Sustain our Communities. Proceedings of the $22^{\text {nd }}$ International Grassland Congress, Sydney, Australia, 2013. New South Wales Department of Primary Industries, Orange, NSW, Australia. p. 1019-1020. 